\title{
An Other Transnationalism : Romanian Jewish Emigrants in Francophone Avant-Garde Literature
}

\section{Sjöberg, Sami}

2019-01

Sjöberg , S 2019 , ' An Other Transnationalism : Romanian Jewish Emigrants in

Francophone Avant-Garde Literature ' , French Studies , vol. 73 , no. 1 , pp. 33-49 . https://doi.org/10.1093/fs/kny258

http://hdl.handle.net/10138/298772

https://doi.org/10.1093/fs/kny258

acceptedVersion

Downloaded from Helda, University of Helsinki institutional repository.

This is an electronic reprint of the original article.

This reprint may differ from the original in pagination and typographic detail.

Please cite the original version. 
FINAL MANUSCRIPT VERSION

Please refer to the published article:

French Studies 01/01/2019, Vol.73(1), pp.33-49

AN OTHER TRANSNATIONALISM: ROMANIAN JEWISH EMIGRANTS IN

FRANCOPHONE AVANT-GARDE LITERATURE

\section{SAMI SJÖBERG}

UNIVERSITY OF HELSINKI

\section{Abstract}

In recent years, avant-garde studies has given rise to several models, such as geopolitical and aesthetic networks, in order to describe the exchanges of influences and innovations that have taken place on a transnational level during the interwar period and the post-war years. However, so far no comprehensive study has examined these networks from an ethnic and cultural perspective, nor has any study focused on the "other transnationalism" that developed alongside French transnational modernism. This "other transnationalism" operates according to a dual dynamic of dispersion and cohesion, since the artists who contributed to it form a cohesive community but were simultaneously affected by geographical dispersion. In practice, this transnationalism assumed various forms that went beyond the canonical forms of the historical French avant-gardes: for instance, Jewish artists had the opportunity to exchange ideas derived from the Jewish tradition, such as the Kabbalah, regardless of which avant-garde movement they were affiliated with. The Jewishness of these artists thus functioned as a lingua franca, but their avant-gardism was likely to exclude them from their religious and cultural community. This liminal position, which stems from the occasional overlap of francophone and Jewish transnationalisms, has allowed francophone Jewish artists to question the autonomy and canon of the French avant-garde. This article analyzes the work of Jewish artists who were born and spent their early, tentative years in Romania, and who contributed to the French avant-gardes abroad as some of their leading voices.

\section{Résumé}


Ces dernières années, la recherche portant sur l'avant-garde a donné naissance à plusieurs modèles, tels que celui des réseaux géopolitiques et esthétiques, afin de décrire les échanges d'influences et d'innovations qui ont eu lieu à un niveau transnational entre-deux-guerres et dans les années d'après-guerre. Cependant, jusqu'à présent, aucune étude approfondie n'a examiné ces réseaux d'un point de vue ethnique et culturel; aucune étude n'a porté sur l'“autre transnationalisme" qui s'est développé parallèlement au modernisme français transnational. Cet "autre transnationalisme" fonctionne selon une double dynamique de dispersion et de cohésion, puisque les artistes qui y ont contribué forment une communauté cohésive cependant affectée par la dispersion géographique. En pratique, ce transnationalisme adopte diverses formes qui vont au-delà des formes canoniques des avant-gardes françaises historiques: par exemple, les artistes juifs avaient la possibilité d'échanger des idées issues de la tradition juive, comme la Kabbale, quelque soit le type d'avant-garde auquel ils appartenaient. Le judaïsme de ces artistes fonctionnait ainsi comme une lingua franca, mais leur avant-gardisme était susceptible de les exclure de leur communauté religieuse et culturelle. Cette position liminaire, qui découle du chevauchement occasionnel des transnationalismes francophones et juifs, a permis aux artistes juifs francophones de remettre en question l'autonomie et le canon de l'avant-garde française. Cet article analyse les travaux d'artistes juifs qui sont nés, ont grandi et ont été formés en Roumanie, et qui ont contribué aux avant-gardes francophones à l'étranger en tant qu'acteurs majeurs.

$<\mathrm{TX}>$ The Romanian-born Jewish poet Ilarie Voronca declared in the Surrealist review ипи that 'of all NATIONS I choose imagi-NATION'. ${ }^{1}$ By 1928 he was already disappointed with the growing nationalism of his native country, intrigued by the artistic avant-garde, and had had his first taste of French cultural life. A distinct French cultural presence was manifest in the pages of $и п u$ in the form of contributions by André Breton, Paul Éluard, and Robert Desnos, among others. Arguably, Voronca's statement on imagination can be seen in the light of the avant-gardist topos of denouncing all nations in favour of a nationless/stateless utopia, but it also manifests transnationalism in its efforts to circumvent conventional categories of belonging, such as nation or

1 '[D]intre toate NAŢIUNILE, aleg imagi-NAŢIUNEA'; Ilarie Voronca, 'Ora 10 dimineaţa', unu, 1 (1928), 6 (6). All translations are by the author unless otherwise stated. 
ethnicity, during a period when the nationalist ideals of the nineteenth century had become hegemonic in Europe. Therefore, Voronca seems to aspire to undermine any 'national' sense of ego, that is, a subjective identification with a nation. In line with Voronca's pungent yet playful announcement, transnationalism is here understood as intersecting flows of ideas, cultural products, and people across national borders. This article investigates transnationalism as a feature of avantgarde literature, especially in its Franco-Romanian Jewish context.

$<\mathrm{P}>$ Literary transnationalism is a fairly novel term, and it has a mediating role in charting the relationships between national literatures and globalization. ${ }^{2}$ Peter Morgan notes that in the global literary environment, transnationalism signifies a departure from the intra-national implications of multiculturalism. Literary transnationalism, for one, 'identifies that point at which two or more geo-cultural imaginaries intersect, connect, engage with, disrupt or conflict with each other in literary form'. ${ }^{3}$ Indeed, transnational and postcolonial discussions tend to focus on dichotomies between the so-called insiders and outsiders while the relationships between avantgarde authors and their cultural, ethnic, and religious identities were more nuanced and ambivalent. Even though the avant-gardes of the first half of the twentieth century did not operate in a global

\footnotetext{
${ }^{2}$ Literary transnationalism is a more apt theoretical frame for the literary avant-gardes than the various versions of 'world literature'. For instance, taking cues from Immanuel Wallerstein's worldsystems theory, Pascale Casanova regards the literary system autonomous of politics and emphasizes the significance of Paris as a centre of literary exchange; Casanova: La République mondiale des lettres (Paris: Seuil, 1999), pp. 24, 62-63. In this sense, Alexander Beecroft's historical-genealogical typology of world literatures is useful, as global literature consists of literatures 'whose linguistic reach transcends national, even continental, borders'; Beecroft, 'World Literature without a Hyphen: Towards a Typology of Literary Systems', New Left Review, 54 (2008), 87-100 (98).

${ }^{3}$ Peter Morgan, 'Literary Transnationalism: A Europeanist's Perspective', Journal of European Studies, 47 (2017), 3-20 (14).
} 
environment (at least not in the sense the term is currently understood), their aims and practices were characteristically extra-national — or, in a word, trans-national.

$<\mathrm{P}>$ Transnational literatures challenge historical ways of thinking, which in literary history are often based on the terms of nations and linguistic regions (such as Sudeten Germans). Such literatures may also establish a cross-cultural system where speakers of many languages share a common literary idiom. Yet, avant-garde literature may be considered inherently transnational in character, even though its study has mainly been based on national languages. ${ }^{4}$ For instance, Dada was never merely its Swiss, French, American, or German incarnation. Rather, it was supposedly a cosmopolitan way of thinking that was meant to be appropriated in and by a variety of literary cultures. This was the aim of the Romanian-born Tristan Tzara with his project Dadaglobe, an anthology that would have displayed various Dadaists from across the world. ${ }^{5}$ Crossing national boundaries was indeed one of the main aims of transnational avant-garde writing. Even linguistic borders were crossed in multilingual poetry (for example, Tzara's poem 'L'Amiral cherche une maison à louer'), by portmanteau words, and through transrational 'languages' (such as Velimir Khlebnikov's zaum or Isidore Isou's visual poetry). This aim of crossing borders also resulted in various strategies to counter othering, evident in the history of the avant-gardes, especially in a

\footnotetext{
${ }^{4}$ In the context of the avant-garde, transnationalism has political significance. Hence, it should be noted that the politics of the avant-garde were not unilaterally leftist or progressive. For instance, the fascist inclinations of Italian Futurism and British Vorticism are well documented, but a discussion on the potential political conservatism — or, indeed, whether fascism was politically conservative - of these movements is beyond the scope of this article.

5 Tzara's Dadaglobe was, however, primarily a transatlantic endeavour lacking, for instance, Japanese Dada altogether. Adrian Sudhalter has compiled the works included in Tzara's schematic plans for the project and this major work has been published as Dadaglobe Reconstructed (Zurich: Kunsthaus Zürich, 2016), together with various exhibitions.
} 
colonial context. An instance of such subversion is the Japanese Futurism of Hirato Renkichi with a distinct emphasis on the taishō period as its cultural background. ${ }^{6}$

$<\mathrm{P}>$ In Europe, the cross-border exchange between France and Romania in the field of avant-garde literature represents a transnationalism that resulted in a body of works that are not French per se but are nevertheless essential for the French avant-garde canon. ${ }^{7}$ This transnationalism produced a geopolitical multipolarity where aesthetic paradigms were not independently developed in the so-called centres (such as Paris, Vienna, or Berlin) but rather in 'transnational spaces' ${ }^{8}$ It can be argued that transnational aesthetic paradigms were nevertheless developed in particular centres even as such paradigms claimed to eschew these centres. However, such an argument overlooks the fact that, for instance, Dada was launched in Switzerland by German, French-German, and Romanian artists, with Sophie Taeuber-Arp being the only Swiss native in Cabaret Voltaire. Such circumstances constitute a multifaceted transnational space, because a fair number of these people were ethnic Jews. However, Zurich cannot be regarded as an inter-war artistic centre akin to the aforementioned centres: it did not spur further avant-garde movements; nor had it previously done so. Neither can Bucharest be considered an inter-war centre,

\footnotetext{
${ }^{6}$ The Russian Futurist David Burliuk would dub Hirato as the Japanese Marinetti, regardless of the idiosyncratic style of his Japanese Futurism. Burliuk thus branded Hirato as the other in relation to European culture; Kinoshita, Shuichiro, and David Burliuk: Miraiha towa? kotaeru. Tokyo: Chuo bijutsusha, 1923. Facsimile edition Tokyo: Nihon tosho senta, 1990.

${ }^{7}$ For instance, Tzara's works are often regarded as French literature, but this approach disregards his biography and cultural affiliations. For a thorough account of these aspects, see Maurice Hentea, TaTa Dada: The Real Life and Celestial Adventures of Tristan Tzara (Cambridge, MA: MIT Press, 2014), pp. 6-23.

${ }^{8}$ Transnational spaces consist not only of material geographies (such as trade or labour migration) but also of symbolic and imaginary geographies through which one seeks to make sense of the transnational world; see Peter Jackson, Philip Crang, and Claire Dwyer, 'Introduction' to Transnational Spaces, ed. by Jackson, Crang, and Dwyer (London: Routledge, 2004), pp. 1-23 (p. $3)$.
} 
even though it gave rise to the unique Romanian integralism. ${ }^{9}$ In line with this notion, the current understanding of the European avant-gardes highlights transnational networks, paradigmatic parallelism, and linguistic multiplicity, rather than rigid unilateral relations between centres and peripheries. ${ }^{10}$ However, the characteristics of these networks and coteries have not so far been sufficiently researched from an ethnic-cultural aspect. ${ }^{11}$ As a result, even fairly recent findings are generalizations or individual microhistories that do not unveil the multifaceted character of the phenomenon.

$<\mathrm{P}>$ As noted, one of the features facilitating cross-border exchange is language, and the Romanian francophilia of the early twentieth century is well documented. ${ }^{12}$ Hence, this article

\footnotetext{
${ }^{9}$ Integralism managed to integrate Futurist, Dadaist, Constructivist, and Surrealist influences, in a creative Romanian synthesis. See Ion Bogdan Lefter, Recapitularea modernității: pentru o nouă istorie a literaturii române (Pituești: Editura Paralela 45, 2000), pp. 32-33.

${ }^{10}$ An illustrative example of these trends is provided by the European Network for Avant-Garde and Modernism Studies book series, published from 2009 onwards. For a listing, see European Network for Avant-Garde and Modernism Studies, 'Book Series', <http://www.eameurope.be/node/2> [accessed 14 September 2018].

11 The Jewish ethnic-cultural aspect is terminologically somewhat problematic, because in Jewish studies definitions of Jewishness range from genetic studies (especially in medicine, which has caused concerns of future anti-Semitism) to considering it a social construct. Even though aesthetic modernity emphasizes cultural aspects, in the particular case of this article the ethnic and cultural aspects are mutually dependent, especially due to the (ethnic) self-awareness raised by antiSemitism the authors encountered. For instance, in 1938 Royal Decree 169 forced Romanian Jews to reclaim their citizenship. Even though avant-gardists such as Marcel Janco and M. H. Maxy (pen name of Max Herman) were successful in claiming their civic rights, 36.3 per cent of Romanian Jews lost theirs. Hence, the contemporary reality in Romania was not merely a case of culturemotivated exclusion. For a more detailed discussion, see Radu Stern, 'Jews and the Avant-Garde: The Case of Romania', in Jewish Aspects in Avant-Garde: Between Rebellion and Revelation, ed. by Mark H. Gelber and Sami Sjöberg (Berlin: De Gruyter, 2017), pp. 35-52 (pp. 43-45).

${ }^{12}$ Relevant research includes (but is not limited to) the Franco-Romanian special issue 'FranceRomania: Twentieth-Century Cultural Exchanges (ed. by Gavin Bowd) of Forum for Modern
} 
focuses on a phenomenon that can best be described as an 'other francophone transnationalism', which emphasizes that there were several overlapping transnationalisms in Europe at the time. Firstly, French was not the first language of the writers I will examine even though it became the primary language of their literary expression — early on in some cases while somewhat gradually in others. Secondly, Voronca, Tzara, Claude Sernet, Victor Brauner, Gherasim Luca, and Isidore Isou were francophiles who were born in Romania but arguably their transnationalism was based on an alternative affinity, namely their Jewish background. In fact, Yiddish was the mother tongue of at least Tzara, Isou, and Luca, but at the time French (together with German) functioned as a European lingua franca and had a firm standing in Romanian intellectual circles.

$<\mathrm{P}>$ On account of their linguistic abilities and aesthetic sensibility, Romanian Jewish writers were not as a rule to be found on the margins of such French avant-gardes as Dada, Surrealism, or Lettrism. ${ }^{13}$ Rather, they were key players who were able to register a seminal impact in the major manifestations of the individual groups. As such, the Romanian Jewish involvement in the French avant-garde was not a case of 'minor transnationalism', where minorities affect the cultural production of their current homeland. ${ }^{14}$ Indeed, in the case of Romanians in France, they steered this production. Tzara and the brothers Janco, for instance, were prominent Dadaists. Brauner, Voronca, and Sernet were renowned Surrealists, and Isou founded the Lettrist movement, which became one of the more influential movements in post-war France together with

Language Studies, 36.2 (2000); Lucian Boia, Romania: Borderland of Europe, trans. by James Christian Brown (London: Reaktion Books, 2001); Monica Spiridon, 'Paris, “Terre d'asile”, Neohelicon, 1 (2004), 61-67; and Anne Frémont-Vanacore, La France en Europe (Paris: Armand Colin, 2009).

${ }^{13}$ See Sami Sjöberg, The Vanguard Messiah: Lettrism between Jewish Mysticism and the AvantGarde (Berlin: De Gruyter, 2015).

${ }^{14}$ For a useful discussion on the concept, see Ali Behdad, 'Post-Colonial Theory and the Predicament of "Minor Literature", in Minor Transnationalism, ed. by Francoise Lionnet and Shumei Shi (Durham, NC: Duke University Press, 2005), pp. 223-36. 
Situationism. In the early 1940s and before relocating to France, Luca was involved in the Bucharest Surrealist group only to be hailed as one of the finest francophone poets by the philosopher Gilles Deleuze: 'Gherasim Luca est un grand poète parmi les plus grands'. ${ }^{15}$ In other words, these figures were at the very core of the French avant-garde canon from the late 1910s to the early 1950s.

$<\mathrm{P}>$ This article investigates how the ethnic-cultural background of these writers was reflected in their transnational avant-garde activity. As a case in point, the continuation of the Jewish tradition and how it adapted to new cultural and social situations was illustrative of the avant-gardists' use of the Jewish textual tradition and mysticism (the Kabbalah). The Kabbalah emerged around the late twelfth century in southern France and Catalonia as a method, discipline, and school of thought for unconventional Torah study. ${ }^{16}$ Its unconventionality derived mainly from its peculiar textual techniques, developed by Kabbalists themselves with the aim of attaining some aspect of divinity.

$<\mathrm{P}>$ The avant-gardists of Jewish origin used the terms 'Kabbalah' and 'Kabbalistic' interchangeably as cultural identifiers, especially when relating to texts that were in some manner regarded as a continuation of the textual tradition of Jewish mysticism. This 'Kabbalistic topos' was not religious per se, but utilized Kabbalistic rhetoric and focused on the ways the Kabbalah suggested paths of achieving 'subjective transcendence', that is, a way of connoting to what lies 'beyond language' by the means of and in the frame of language. Therefore, the topos was first and foremost a poetic endeavour where religious allusions were mainly secondary.

\footnotetext{
${ }^{15}$ Gilles Deleuze and Claire Parnet, Dialogues (Paris: Flammarion, 1977), p. 10.

${ }^{16}$ See Gershom Scholem, Die jüdische Mystik in ihren Hauptströmungen (Frankfurt a.M.: Suhrkamp, 1967), pp. 35-37.
} 
$<\mathrm{P}>$ The sporadic but recurring uses of the Kabbalah in avant-garde literature were anachronistic, representing a certain medievalist inclination in the avant-garde. ${ }^{17}$ For instance, Isou explicitly identified his avant-gardist methods with those of medieval Kabbalah. ${ }^{18}$ Arguably, writers of Jewish origin were drawn to the idea of nationlessness and transnationalist practices in the avantgarde and found in the Kabbalah a historical, 'pre-national' foundation for their work, a foundation that preceded the modern nation states. Yet, there is no simple and straightforward answer as to why the avant-gardists chose the Kabbalah, because the reasons for the newly awakened interest of authors such as Yvan Goll, Luca, and Isou remains unclear. The most likely interpretation is that the avant-gardists found in the Kabbalistic corpus a repository of original and idiosyncratic conceptions of language, meaning production, and textual techniques, which went hand in hand with the avantgardist tendency to subvert common sense and normalized logic. There are two aspects that support this interpretation. Firstly, the avant-gardists, especially of Jewish origin, were familiar with the use of the Kabbalah in the avant-garde, for instance, its involvement in the Neue Club early expressionism by the neo-Kabbalist Oskar Goldberg, among the artists evoking the Russian Jewish renaissance of the 1910s and the Polish Yiddish avant-gardists during the 1920s. ${ }^{19}$ Secondly, ethnic discrimination during the 1930s and 1940s may have led even assimilated Jews to investigate their roots and the Jewish tradition — in other words, to investigate what made them particular in the

${ }^{17}$ Even though several writers and artists of Jewish origin were interested in the Kabbalah and had gained a relatively fluent understanding of it during the inter-war period, the 'Kabbalistic topos' in avant-garde literature first blossomed after the Holocaust.

${ }^{18}$ Isidore Isou, L'Agrégation d'un nom et d'un messie (Paris: Gallimard, 1947), p. 355.

${ }^{19}$ Some German Jews came into contact with the Kabbalah through the German romanticism of Friedrich Schlegel and Friedrich Schelling. Schelling and Franz Molitor were key figures in the incorporation of Kabbalah to German philology and idealistic philosophy. See Giulio Busi, 'Beyond the Burden of Idealism: For a New Appreciation of the Visual Lore in the Kabbalah', ed. by Boaz Huss, Marco Pasi, and Kocku von Stuckrad, Kabbalah and Modernity: Interpretations, Transformations, Adaptations (Leiden: Brill, 2010), pp. 29-46. 
eyes of the anti-Semites. In the particular case of Dada, the Kabbalah may have appealed to the ethical, cosmic, and 'quasi-Buddhistic' affinities found in the movement and to its aspirations to overthrow personal, rational, and national senses of ego. The widespread interest in the Kabbalah at the time is a now-forgotten border-crossing literary feature, which manifests the 'other transnationalism'. It should be noted that the poetic interest in the Kabbalah was typically — but not exclusively — francophone, especially after the early 1940s when the Nazis destroyed much of the German- and Yiddish-speaking Jewish population of Europe.

$<\mathrm{TB}>$

$<\mathrm{SH}>$ Transnationalism, othering, and avant-garde literature

$<$ TX $>$ Accounts of Romanian artists' and writers' involvement in Western European avant-garde movements have been cumulative over the last decade, but many of these studies neglect the Jewish background of the people they focus on. ${ }^{20}$ Accounting for this fact is essential as many of these figures were not de jure Romanian citizens: Jews in Romania did not gain citizenship until 1923, even though families would have lived there for generations. ${ }^{21}$ Beyond citizenship, this issue unearths the multifarious relations between ethnicity, identity, and cultural ties at play in the lives of the émigrés, which are, furthermore, manifest in their artistic production and critical writings.

$<\mathrm{P}>$ Even though the focus of this article is on Jewish ethnicity and its manifestations in the literary output of certain avant-gardist writers, it would be inappropriate to talk about

${ }^{20}$ Most notably, the recent From Dada to Infra-noir: Dada, Surrealism, and Romania, ed. by Monique Yaari and Timothy Shipe (= special issue, Dada/Surrealism, 20.1 (2015)), which focuses on Romanian avant-gardists, as does Ion Pop's La Réhabilitation du rêve: une anthologie de l'avant-garde roumaine (Paris: Maurice Nadeau, 2006), or Paris-Bucharest, Bucharest-Paris: Francophone Writers from Romania, ed. by Anne Quinney (Amsterdam: Rodopi, 2012). Tom Sandqvist's Dada East: The Romanians of Cabaret Voltaire (Cambridge, MA: MIT Press, 2006) takes Jewishness as a point of departure, but is somewhat speculative in its results.

${ }^{21}$ See Irini Livezeanu, Cultural Politics in Greater Romania: Regionalism, Nation Building and Ethnic Struggle, 1918-1930 (Ithaca: Cornell University Press, 1995), pp. 122-23. 
diaspora rather than transnationalism. Diaspora would foreground 'an imagined community living away from a professed place of origin'. ${ }^{22}$ In the case of Jews, that would signify a relation, at least a mental one, to Palestine/Israel and therefore best describe the existential situation of the Eastern European Ashkenazim. The way the concept has been applied in recent scholarship, diaspora would denote a stable group or community and refer to a multi-generational pattern (longue durée). Transnationalism, for one, addresses more recent migrant flows and bilateral cross-border exchange: it focuses on mobility and active networks. ${ }^{23}$ It is a far more suitable term to cover voluntary emigration, as the avant-gardists were not as a rule refugees but émigrés.

$<\mathrm{P}>$ In literature, transnationalism defies cultural affiliations. As Arif Dirlik notes, the construction of identities in 'transnational' literature is compounded by 'the question of the cultural belonging of literature as it is divorced from earlier associations with nations and national languages'. ${ }^{24}$ In the case of polylingual avant-garde writing (for example, neologisms constructed using more than one language), one is pressed to differentiate such writing from national languages, but even experimental writing that criticizes conventional modes of meaning production utilizes the existing conventions of (a national) language. ${ }^{25}$

$<\mathrm{P}>$ Transnationalism in the Franco-Romanian avant-garde is often connected to mobility, self-realization, and the utilization of the Jewish textual tradition. ${ }^{26}$ In addition, the

${ }^{22}$ Steven Vertovec, 'Cosmopolitanism', in Diasporas: Concepts, Intersections, Identities, ed. by Kim Knott and Seán McLoughlin (London: Zed Books, 2010), 63-9 (p. 63).

${ }^{23}$ See Thomas Faist, 'Diaspora and Transnationalism: What Kind of Dance Partners?', in Diaspora and Transnationalism: Concepts, Theories and Methods, ed. by Rainer Bauböck and Thomas Faist (Amsterdam: Amsterdam University Press, 2010), pp. 9-34 (pp. 13, 22).

${ }^{24}$ Arif Dirlik, 'Literature/Identity: Transnationalism, Narrative and Representation', Review of Education, Pedagogy, and Cultural Studies, 24 (2002), 209-34 (210).

${ }^{25}$ Hence, the broader concept of 'francophone writer' is suitable, because it contains the idea of a sphere of influence, an influence that has been disseminated by the transnational networks.

${ }^{26}$ See Sjöberg, The Vanguard Messiah, pp. 16-24. 
polyglottism of Jewish writers from Romania and their relatively late-gained citizenship challenge the idea of national belonging. In fact, the history of the Romanian avant-garde is by and large a history of emigration. The cultural history of Romania, which is explained in more detail below, first facilitated and encouraged emigration and cultural exchange, but during the late 1930s emigration was accelerated by anti-Semitism. Finally, in the 1940s, the émigrés turned into exiles due to fascism and, later on, communism.

$<\mathrm{P}>$ One of those fleeing from communism was Luca, who joined the Romanian expatriate community in Paris in $1952 .{ }^{27}$ After being persecuted in Romania first by the antiSemites and then by communists, he defined himself as an 'apatrid'. Taking this 'imminent otherness' a step further, Luca called himself an 'étranjuif', a sort of 'stranJew' — a stranger among other people who is also a stranger to himself. ${ }^{28}$ As a way to emphasize this identification on the level of literature, Luca drew an explicit affinity between his poetry and the Kabbalah. ${ }^{29}$ $<\mathrm{P}>$ The adoption of Kabbalistic elements was logical: the Kabbalah was created by people in diaspora and included inventive manipulation of texts. This (Jewish) people was culturally transnational and the Kabbalah — written in Hebrew — preceded national languages. In other words, the themes and textual techniques of the Kabbalah were transnational in character even though they were applied in avant-garde writing in national languages. Moreover, the original Kabbalah was doubly beyond the reach of the major European gentile population: the Hebrew language was relatively unknown outside the religious sphere, and the modes of thought present in

\footnotetext{
${ }^{27}$ Paris was a logical destination for Luca, as he had already been in contact with French Surrealists and corresponded with his compatriot and friend Brauner in the 1940s. Brauner had moved to Paris already in 1930 .

${ }^{28}$ Gherasim Luca, 'Cahier de 1962', Bibliothèque littéraire Jacques Doucet, fonds Ghérasim Luca, Paris, 1962.

${ }^{29}$ Ghérasim Luca and Tilo Wenner, ... pour quelques amis lointains... (Paris: Aux Éditions des cendres, 2014), p. 78.
} 
the Kabbalah were equally unfamiliar. Hence, even though the avant-gardists presented Kabbalistic elements in national languages such as French, the resulting poetic style and the rather idiosyncratic modes of thought were still considered awkward. ${ }^{30}$ This is, perhaps, nowhere as poignant as in Luca's poetry, which has been characterized as untranslatable even though — or because — its style is peculiar also in French. As his poem 'Passionnément' illustrates, Luca's poems have a broad horizon of meaning and thus undermine any single linguistic belonging:

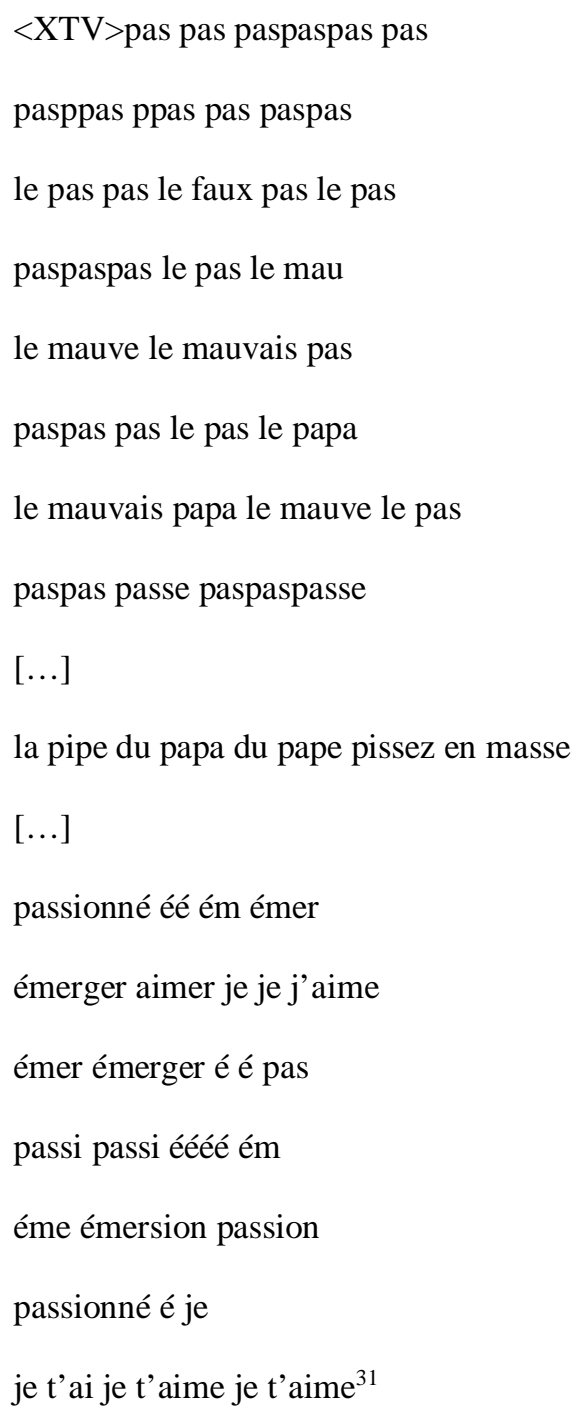

\footnotetext{
${ }^{30}$ This was evident already in the 1920s in Germany, where the avant-garde was criticized for producing a form of Judaism that was unrecognizable to the old guard. See Leopold Fuchs, 'Expressionistiches Judentum', Jüdisch-liberale Zeitung, 4 (1924), 1-2.

${ }^{31}$ Ghérasim Luca, 'Passionnément', in Le Chant de la carpe (Paris: José Corti, 1986), pp. 87-92.
} 
$<$ TX >Luca's poem reads like an incantation performed in an ecstatic state, an asubjective autonomous functioning of language or an algorithm trying to make sense of and assimilate a (foreign) language. In any case, the processes of meaning-making seem not fall under the control of the subject and hence they point towards the 'beyond language'. The stammered, atomistic building blocks of language provide surprising allusions, even to neuropsychiatric disorders such as Tourette's syndrome — that is, sources other than religion. Aptly, commenting on Luca's poetry, Dominique Carlat suggests that Luca replaced the metaphysical and theological dimensions of the Kabbalah with a poetic emphasis. ${ }^{32}$

$<\mathrm{P}>$ Kabbalistic rhetoric does, however, carry with it latent religious influences. Such influences are apparent in Voronca's manifesto, 'Gramatică' [Grammar]. ${ }^{33}$ He promoted an alternative canon consisting of prominent figures in European experimental art, such as Mallarmé, Rimbaud, Tzara, and Marcel Janco — the latter two being Voronca's Jewish compatriots, whereas the French authors proved his francophilia. Voronca echoes the works of these predecessors when stipulating the necessity for a new approach to words, which would establish a new logic. A paradox is already present here: how can the 'radically new' draw from literature written more than thirty years earlier? Similar specious neophilia proved to be an overarching feature of the various avant-gardes, together with various utopian and political aims. The paradox of the 'old' and the 'new' is especially evident in the adoption of the Kabbalah.

$<\mathrm{P}>$ In the light of such extensive neophilia, the complete omission of religion and its rhetoric would seem to be necessary. Yet, amid Voronca's rampant anti-traditionalist discourse a peculiar statement can be found that mirrors his ethnic-cultural background: 'Each artist must be the originator of novel principles, descending through the concert of fulgurations atop Mount Sinai with

\footnotetext{
${ }^{32}$ Dominique Carlat, Gherasim Luca l'intempestif (Paris: José Corti, 1998), p. 47.

${ }^{33}$ Ilarie Voronca, 'Gramatică', Punct, 6-7 (1925), 13.
} 
the tablets of a new logic in his hands. ${ }^{34}$ This ambiguous statement describes and envisions the revealing of the Torah by God to Moses on Mount Sinai and attributes to the Tablets of the Law a novel sense: that is, a ground for a new logic. While Voronca promoted his new avant-gardist logic, he concurrently suggested that Judaism had created a new logic as well, which perhaps refers to monotheism amid polytheistic or pagan religions. Voronca contextualized his tradition-recalling statement by claiming that a novel experience - which is free from conventional modes of thought — would result in a seemingly 'neological', alternative logic, and that this logic would in time be subsumed into 'old time logic'. The inner dynamics of the avant-garde are apparent in the dialectic movement between the new and the old, in which the current 'new' becomes commonplace and is eventually replaced.

$<\mathrm{P}>$ The Kabbalah was able to respond to this need with its idiosyncratic ideas, such as those concerning 'new' epistemic transactions, ecstatic experiences, and language. Despite Voronca's somewhat enigmatic formulation, he obviously referred to a historical continuity between his avant-gardist experiments and the Jewish tradition. ${ }^{35}$ The only directly confessional mode relating to his identity is the collection of poems titled Petre Schlemihl (1932), where he compares himself with a countryless wandering Jew who is rejected by society: 'an Ahasuerus casting no shadow'. He writes:

$<$ XTV $>$ You have dragged me away from courts drenched by rain,

And you have discarded me in December from the stoves with redhot crackling fire,

I wander away from the streets that are filled with noise,

34 'Orice artist trebuie sa fie aducatorul unor alte principii, scoborand in concertul de fulgere de pe muntele Sinai cu tablele logicei noi in maini' (Voronca, 'Gramatică', p. 1).

${ }^{35}$ According to Carol Iancu, Voronca was influenced by his Jewish identity and never converted; Iancu, 'Voronca, Ilarie', trans. by Anca Mircea, The YIVO Encyclopedia of Jews in Eastern Europe, <http://www.yivoencyclopedia.org/article.aspx/Voronca_Ilarie> [accessed 14 September 2018]. 
And you have whipped me in market places as you whip old horses. ${ }^{36}$

$<$ TX > Voronca refers to a novella, Peter Schlemihl (1814), written in German by the exiled aristocrat, Adelbert von Chamisso. Obviously, Voronca's audience were expected to know the story and interpret the implicit meaning of the avant-gardist poet as a Jew.

$<\mathrm{P}>$ Overall, Jewish participation in the avant-gardes is noteworthy because it can be seen as an alternative path to modernization. The avant-garde provided an alternative world view to those uninterested in religious orthodoxy or bourgeois assimilation. In this context, the question of identity may be approached using the terms 'close other' and 'double outsider'. Both terms are essential for an understanding of francophone transnationalism, especially its Jewish variant. The terms reflect the potential of assimilation, that is, how easily a person could become a member of the local majority. Assimilation usually occurred according to the educational, occupational, and cultural conditions established by the middle class, which is why assimilation may not have been very attractive to many young avant-garde artists. Moreover, it also proved to be difficult in many cases, such as that of Tzara, whose Dada production was considered to be a 'foreign import' both in his native Romania, from where he emigrated, and in Switzerland, to where he relocated. ${ }^{37}$ Likewise, with an allusion to the Kabbalah, Isou's arrival in Paris was chronicled as an import of 'sa culture médiévale étrangère'. ${ }^{38}$ Both of them were apparently subject to othering.

$<$ P $>$ Piotr Piotrowski's concept of intra-European otherness is useful in the context of othering related to the avant-garde. By adopting a postcolonial frame, he distinguishes the non-

\footnotetext{
${ }^{36}$ Voronca, trans. by and quoted by Andrei Oişteanu in Inventing the Jew: Antisemitic Stereotypes in Romanian and Other Central-East European Cultures (Lincoln: University of Nebraska Press, 2009), p. 341.

${ }^{37}$ See Hentea, TaTa Dada, p. 150, and Octavian Goga, Mustul care fierbe (Bucharest: Imprimeria statului, 1927), p. 36.

${ }^{38}$ Robert Estivals, Le Signisme: l'histoire du schématisme I (Paris: L'Harmattan, 2005), p. 51.
} 
European other (such as Hirato Renkichi) from a 'close other', whose place is 'on the margins of European culture, outside the centre but still within the same cultural frame of reference'. ${ }^{39}$ Voronca's identification as Ahasuerus was a symptomatic case of such othering. Such a definition applies to local manifestations of the avant-garde in East Central Europe but not to FrancoRomanian bilateral artistic exchange in the avant-garde. Instead of remaining outside the centres in the relatively small Bucharest or the Eastern European shtetlekh, Jewish artists often formed alternative undercurrents (manifest, for instance, in their adoption of the Kabbalah) in the metropolitan centres of the avant-garde. In other words, they represented otherness in these centres, but this otherness occurred in the same (transnational) space with other French avant-garde production.

$<\mathrm{P}>$ The most illuminating example of 'close otherness' in Paris was the German Jewish author Carl Einstein, whose book Negerplastik (1915 [Negro Sculpture]) introduced African art to the European sphere. In this work, the African imagery and cultural heritage are projected as the exotic, non-European other, while Einstein himself remained in the position of the 'close other', because Jewishness was one of his European 'lived traditions'. This otherness became evident during Einstein's forced exile when he lamented the extent of his secular upbringing, since Judaism or the discourses of Jewishness could have served him as a lingua franca in France; in fact, it was required of him in order to become acquainted with French Jews. ${ }^{40}$

$<\mathrm{P}>$ Yet the existential situation was altogether different for the French-speaking Romanian Jewish avant-gardists than it was for Einstein. This is evident in their explicit accounts of their Jewishness. When Brauner was asked if his nationality, his forebears, or his experiences as a

${ }^{39}$ Piotr Piotrowski, 'Toward a Horizontal History of the European Avant-Garde', in Europa! Europa? The Avant-Garde, Modernism and the Fate of a Continent, ed. by Sascha Bru and others (Berlin: De Gruyter, 2009), pp. 49-58 (p. 53).

${ }^{40}$ Einstein quoted in Klaus Kiefer, Avantgarde, Weltkrieg, Exil: Materialien zu Carl Einstein und Salomo Friedlaender/Mynona (Frankfurt a.M.: Lang, 1986), p. 26. 
Jew were relevant to understanding his art, he replied 'no' only after striking out 'yes'. ${ }^{41}$ Not all were as hesitant as Brauner on the influence of their identity on their art. Introducing a firmer identification, Isou stated: 'Je suis tellement Juif que c'est peut-être le seul mot dans ma vie que j'écrirai avec majuscule, sans avoir l'impression d'ajouter une dimension, de combler une irrégularité. ${ }^{42}$ While Tzara had sought not to reveal his Jewishness in Switzerland or France, Isou celebrated it in the immediate wake of the Holocaust. Such identifications placed the Jewish avantgardists in a difficult position, which could be called 'double outsiderdom'. It signifies that the Romanian Jewish avant-gardists were simultaneously too modern and radical to be included in the conservative Jewish community (which followed Jewish rituals and law), and too Jewish to be part of the mainstream population (in their case Romanian assimilation was hindered by anti-Semitism and French assimilation by their 'foreignness', even though some would later be naturalized). ${ }^{43} \mathrm{~A}$ further dimension of outsiderdom was added by their activities in the avant-garde, which was a marginal practice to begin with. This double outsiderdom is evident in the reactions to their Jewish peers by Hugo Ball and André Breton, who were at least to some extent anti-Semites. ${ }^{44}$ The Kabbalistic topos was an instance of the use of cultural identifiers that made a certain group distinct in the contemporary nationally accentuated conceptions of literature and culture.

$\langle\mathrm{TB}\rangle$

${ }^{41}$ Victor Brauner, Écrits et correspondances 1938-1948, ed. by Camille Morando and Sylvie Patry (Paris: Éditions du Centre Pompidou, 2005), p. 367. According to James Lord, the Kabbalistic topos functioned as a cultural identifier when Brauner looked favourably on the artist Dora Maar's postwar interest in the Kabbalah. James Lord, quoted by Camille Morando in ibid., p. 231.. ${ }^{42}$ Isou, L'Agrégation d'un nom, p. 209.

${ }^{43}$ Isou became a naturalized French citizen in 1980. Luca, however, lived paperless in Paris until his suicide in 1994.

${ }^{44}$ See Hans Richter, Dada: Art and Anti-Art (New York: Oxford University Press, 1965), p. 16, and Zoë Roth, 'Frontière humaine: Race, Nation, and the Shape of Representation in Claude Cahun', in Jewish Aspects in Avant-Garde, ed. by Gelber and Sjöberg, pp. 119-140 (pp. 126-27). 


\section{$<\mathrm{SH}>$ The Kabbalah in Franco-Romanian avant-garde}

$<\mathrm{TX}>$ In a letter to the artist Dora Maar, Brauner used gematria to 'decipher' the twelve letters of the name Pablo Picasso, her former lover. ${ }^{45}$ Such playful use speaks for the recontextualization of the mystical techniques. The most renowned Kabbalistic techniques are gematria, temurah, and notarikon. Gematria is based on the numerical value of letters in Hebrew, which does not use distinct numerical symbols. The technique explains a word or group of words according to the numerical value of the letters, or by substituting other letters of the alphabet for them in accordance with a set of rules. The temurah, for one, expresses the belief that non-existent letters are as meaningful a part of the verse as those that already exist. Finally, notarikon is the method of interpreting the Hebrew Scriptures by making words from letters taken from the beginning, middle, or end of the words in a sentence. ${ }^{46}$

$<\mathrm{P}>$ The Kabbalistic topos manifests itself not only in poems but also in theoretical texts relating to poetics. A year before declaring his preference of the imagination over nations, Voronca stated that ' $[t]$ he poet communicates with God; his voice has reverberations from the beyond. ${ }^{47}$ This statement is reminiscent of the romantic creator-genius, even though it rephrases one of the fundamental ideas of the Kabbalah: communication with some aspect of divinity. One should also notice that during this period many Jews across the continent knew the Kabbalah, at least on a very general level, so such thinly veiled references were no doubt recognized. Hence, the use of the Kabbalistic topos by the avant-gardists can be seen as a manifestation of the 'other

\footnotetext{
${ }^{45}$ Pierre Arnaud, 'De l'orphisme à Abstraction-Création : la réception de l'œuvre de Kupka dans l'entre-deux guerres', Bulletin de la Société de l'histoire de l'art français (Paris: F. de Nobele, 1995), 249-68 (258).

${ }^{46}$ See Moshe Idel, Language, Torah and Hermeneutics in Abraham Abulafia, trans. by Menahem Kallus (Albany: SUNY Press, 1989), pp. 100-01.

47 'Poetul comunică cu Dumnezeu; glasul lui are răsfrângeri de dincolo'; Ilarie Voronca, 'Note despre poem si anthologie', Integral, 13-14 (1927), 3.
} 
transnationalism' - the audience of which were people familiar with this aspect of the Jewish tradition. In most cases, the audience had to have at least a fair grasp of French. Brauner, for instance, stated that the 'poëte mangeant la cabale pour apaiser sa faim initiatique'. ${ }^{48}$ The obsolete spelling of 'poëte' seems to be intentional, perhaps referring to the historical dimension of writing brought about by the Kabbalah. The abstract hunger he describes obviously alludes to the 'experimental' poetic devices applied in Kabbalistic endeavours. The statement also suggests that Brauner's audience knew the subject. It is noteworthy, however, that nowhere does Brauner limit the interrelation of the poet and Kabbalistic material to Jewish ethnicity. This suggests that the Kabbalistic topos influenced more the form than contents of avant-gardist poems.

$<\mathrm{P}>$ Indeed, the avant-gardes were known already to manipulate language, its rhythm, and its sounds from Filippo Tommaso Marinetti's Futurism onwards — even though earlier examples exist. In a similar but more straightforward manner to Brauner, Luca recalled that his work Héros-limité of 1953 was a 'recueil de poèmes qui reprend sinon à la lettre du moins dans l'esprit d'une même rigueur, la tradition Kabbalistique de langage'.${ }^{49}$ On the one hand, he acknowledges the potential metaphoricity of the term 'Kabbalistic', but, on the other, he links his poems with a particular tradition of textual manipulation and it is in this very sense the Kabbalistic topos carries the excess of the tradition with it. Why call one's poetry explicitly Kabbalistic if not to use it as a cultural identifier in a transnational space? The phenomenon seems to be too widespread among the avant-gardists of Jewish origin for it to be a case of mere mystification.

$<$ P $>$ As noted above, Luca's poems played with homophonic words and ambiguity. He adopted not only Kabbalistic techniques, but the whole notion of language being based on unfixable rather than stable meanings. Accordingly, he stated that: 'l'écriture n'étant pour moi que le "support" — dans le sens alchimique du terme — d'une démarche analogue à la Kabbale (une

\footnotetext{
${ }^{48}$ Brauner, Écrits et correspondances, p. 13.

${ }^{49}$ Luca, in Luca and Wenner, ... pour quelques amis lointains..., p. 78.
} 
Kabbale anarchique et athée, bien sûr, mais non moins rigoureuse que celle des mystiques du Moyen Âge)'. ${ }^{50}$ By this statement Luca draws a line between medieval mystics and his poetics, now only adhering to analogies to the Kabbalah. Indeed, hereby the Kabbalistic topos becomes a cultural identifier.

$<\mathrm{P}>$ The following poem illustrates what Luca himself called a 'purely Kabbalistic poem':

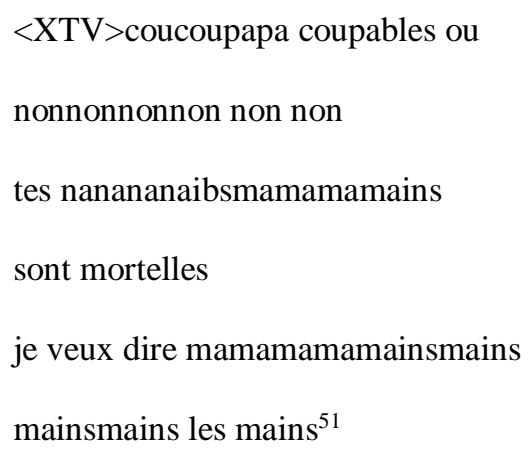

$<\mathrm{TX}>$ The poem destabilizes meaning by means of stuttering that bears both a homophonic and a visual aspect: the repetitive approximation of words in the opening line binds the grammatical elements together. The 'coucoupapa' (lit. 'hellodaddy') precedes and functions as a stuttered version of the main word 'coupables', whereas the final 'ou' echoes the first syllables of the words preceding it. One can read the line literally as 'hellodaddy guilty or' with further deconstructed allusions to paedophilia, including 'tes mains sont mortelles' and 'je veux dire mama'. Yet the homophonic repetitive pattern can be seen as similar to incantations in ecstatic states, which Luca's sound poem readings echo. Technically, Luca's poem repeats individual syllables, whereas the Kabbalah would focus on individual letters. This results from a recodification of a Kabbalistic technique into French, because Hebrew script is abjad — that is, the vowels are not written. Yet,

\footnotetext{
${ }^{50}$ Luca, in Luca and Wenner, ... pour quelques amis lointains..., p. 70.

${ }^{51}$ Luca, in Luca and Wenner, ... pour quelques amis lointains..., p. 80.
} 
Luca's poem is similar to Kabbalistic permutations where letter combinations form various repetitive successions of words.

$<\mathrm{P}>$ Hence, Luca manages to preserve the poetic aspect of the Kabbalah without directly engaging a religious overtone. He also utilized Kabbalistic rhetoric by stating that 'chaque incursion dans la structure intime du mot devant marquer la transgression concrète d'un obstacle intérieur et l'ouverture d'une porte dans mon esprit'. ${ }^{52}$ Luca hereby refers to the 'beyond language': the 'intimate structure of the word' is its grammatical construction and the allusions created by stuttering transgress any unambiguous words. Indeed, the poem speaks multiple meanings and no meanings simultaneously. In fact, such haphazard and coincidental passages were a common result of gematria whereby a seemingly non-sensical instalment could have multiple meanings for the initiated.

$<\mathrm{P}>$ Isou, likewise, sought to unburden literature from the representation of mental concepts in language. His Kabbalah-informed poetry, hypergraphie, transcended national languages by subverting the linguistic contents of language in extremis. The result was a kind of visual Esperanto that was meant to be as 'universally' understandable as painting, even though this aim was never met. However, relating to a Kabbalistic context, the text was also universally 'ununderstandable' as avant-gardists aspired to languages that produce universal unintelligibility, at least in the 'standard' sense of intelligibility (such as zaum). Epistemologically, hypergraphics could not convey (linguistically) communicable meaning due to the invented signs it included. ${ }^{53}$ Isou's utopian project managed to erase the boundaries of writing that still relied on national languages, but subsequently his work became transrational — akin to, but evolved from zaum — thus erasing transnationalism in favour of universalism.

$<\mathrm{P}>$ Isou was keen on diminishing the secular aspect of the Kabbalah in avant-garde

\footnotetext{
${ }^{52}$ Luca, in Luca and Wenner, ... pour quelques amis lointains..., p. 70.

${ }^{53}$ See Sjöberg, The Vanguard Messiah, pp. 109-13.
} 
poetry, which tended to utilize mysticism for poetic rather than spiritual ends. Accordingly, he wrote:

\footnotetext{
$<$ XTT >Cabbale est une lutte systématique contre le romantisme. [...] Le romantisme de la Cabbale n'est pas celui de la grâce extérieure mais le désir d'accumuler tout ce qui parait inconnu. [...] La Cabbale est le résultat de cette suprême défense de la Bible, cette exégèse de la prolongation jusque dans les racines de l'obscur. ${ }^{54}$
}

$<\mathrm{TX}>$ Isou validates the Kabbalah as the foremost means of enquiry into the divine, which 'safeguards' the Jewish tradition by being limited to a certain group of connoisseurs. This is another way of articulating the obscurity of the Kabbalah and its resistance to modern modes of thought, such as national(ist) agendas. Isou's appropriation of the Kabbalah seems to hinder any reading of his work that would define it as particularly French, Romanian, or Jewish. In this sense, it is an instance of the 'other transnationalism'. However, Isou's version of the 'Kabbalistic avant-garde' was an exception to the Kabbalistic topos's rule of applying the poetic aspects of mysticism with limited spiritual content in the context of the avant-gardes. Most writers representing the 'other transnationalism' omitted the religious and spiritual aspects from their work by constraining themselves to the poetic aspects of the Kabbalah.

$\langle\mathrm{TB}\rangle$

$<$ SH>From Romania to transnational spaces: a literature of not belonging

$<\mathrm{TX}>$ The Kabbalistic topos illustrates the ethnic-cultural transnational spaces in francophone literature. In addition, it exemplifies the Jewish avant-garde authors' feelings of outsiderdom (crystallized in Luca's 'étranjuif'). This outsiderdom has a history: the Jewish diaspora in East Central Europe was transnational in character. It became more emphasized during the Russian Revolution, when approximately half a million Jewish refugees from the Russian Pale of Settlement

\footnotetext{
${ }^{54}$ Isou, L'Agrégation d'un nom, p. 282.
} 
arrived in Romania. The refugees were Ashkenazi and spoke Yiddish or Russian rather than Romanian, thus provoking anti-Semitic attitudes among Romanian gentiles against all Jews. ${ }^{55}$ The Ashkenazi were often orthodox Jews, unlike the secular Jewish intelligentsia of Bucharest who sowed the seeds of modern literature in the country.

$<\mathrm{P}>$ Romanian literary modernity had indeed arrived from France, in which the Jewish intelligentsia played a crucial role. ${ }^{56}$ The avant-gardists' correspondence between France and Romania was already lively in the 1920s, when the Romanian avant-garde peaked, shown by numerous avant-garde magazines, such as Contimporanul, 75hp, Integral, and the already mentioned $u n u .{ }^{57}$ A noticeable number of the editors were of Jewish origin. These little magazines were often trilingual (Romanian, French, German) and included original contributions by some of the leading figures of the Continental avant-garde, such as Breton, Marinetti, and Herwath Walden. In fact, contemporary Western writers seldom maintained any sense of periphery and Romanian avant-gardists were regarded as important as those in Vienna or Berlin. In addition, the Romanian magazines were au courant with the topical developments in the avant-garde thanks to their correspondents in Paris, such as Tzara and Benjamin Fondane. Fondane, Voronca, and Mathis Teusch were Integral's Parisian co-editors and the former was in sporadic correspondence with the Romanian avant-gardists. However, following his early interest in the avant-garde in the latter part

${ }^{55}$ See William Brustein and Amy Ronnkvist, 'The Roots of Anti-Semitism: Romania before the Holocaust', Journal of Genocide Research, 2 (2008), 211-35 (220).

${ }^{56}$ See Monica Spiridon, 'The Fate of a Stereotype: Little Paris', PMLA, 1 (2007), 271-4 (271). Moreover, the Romanian elite was mainly educated in France and the intelligentsia of Bucharest was francophone. See Spiridon, 'Paris, “Terre d'asile”, pp. 62-63.

${ }^{57}$ As such, they took part in a broader transnational network of European avant-garde magazines. For instance, the British review Ray: Art Miscellany (1928-1929) contained the contact information of Contimporanul, Der Sturm, and others. 
of the 1920s, Fondane became keen on Shestovian existential philosophy and his literary works characteristically more modernist. ${ }^{58}$

$<\mathrm{P}>$ As emigrants the writers occasionally retrospectively reflected on their native country, as did Sernet by writing that in the 1910s Romania had been a

\begin{abstract}
$<$ XTT $>$ pays beaucoup trop jeune pour que ses structures politiques, sociales et morales, imitées de celles des bourgeoisies occidentales [françaises], fussent suffisamment caractérisées, voire prêtes à opposer une résistance organisée, à se défendre et à riposter, — ni en roumain, langue elle aussi, à part chez quelques rares exceptions, trop peu mûre pour que sa tradition littéraire et ses 'valeurs esthétiques' aient eu le temps de se corrompre, de s'abâtardir et d'engendrer de la sorte le légitime besoin d'un renouvellement, d'une purification, même et surtout au prix d'une iconoclaste brutalité. ${ }^{59}$
\end{abstract}

$<\mathrm{TX}>$ Sernet recognized Romanian culture as distinct from the French — albeit he suggested that the avant-gardists were independent of the conventional and reactionary elements of the Romanian cultural sphere. Thus, Romanian cultural life was a legitimate target for avant-gardist revolt, but as the country did not have the aesthetic means to receive the revolt, it became misplaced and occurred in the French context, which was, to quote Sernet, sufficiently mature. This displacement gave rise to the 'other transnationalism' where Jewish emigrants took part in the French avant-garde regardless of their involvement in the Romanian avant-garde magazines. As the multilingualism of these publications shows, their readership was envisioned to be transnational.

\footnotetext{
${ }^{58}$ For a further discussion on Fondane's relationship with the avant-garde and Judaism, respectively, see Benjamin Fondane, Fundoianu/Fondane et l'avant-garde, ed. by Petre Raileanu and Michel Carassou (Paris: Éditions Paris-Méditerranée, 1999), p. 27-29, and Fondane, Entre Jérusalem et Athènes: Benjamin Fondane à la recherche du judaïsme, ed. by Monique Jutrin (Paris: Lethielleux, 2009).

${ }^{59}$ Claude Sernet, 'Introduction' to Tristan Tzara, Les Premiers Poèmes, ed. by Sernet (Paris: Seghers, 1965), pp. 7-34 (p. 26).
} 
$<\mathrm{P}>$ Naturally, such a transnational participation required an established network. An instance of such is provided by Brauner's letter to Breton in 1938, where he clarifies why many Romanian Jewish artists and writers decided to emigrate to Paris:

\footnotetext{
$<$ XTT >Me voilà enfin ici, où j'ai tant désiré être. Je vous assure que pour moi, ça me paraît magnifique de vivre en France, surtout en ce moment, où vraiment en Europe il n'y a pas un seul endroit habitable. J'ai eu énormément de difficultés de tout ordre là-bas, des choses m'ont férocement retenu et paralysé dans cet ignoble pays [Roumanie]. En plus — la dictature du roi — dissolution de tous les partis politiques et arrestation du moindre suspect, je ne voulais pas être arrêté. ${ }^{60}$
}

$<\mathrm{TX}>$ Brauner recognized Paris as the centre of the contemporary art world, drawing Jews and nonJews alike. Yet, another reason for his emigration was anti-Semitism at home. He refers not only to his activities in the Romanian avant-garde, which had become suppressed under fascist rule, but also to the overall situation of Jews in Romania, which deteriorated quickly during the latter part of the 1930s. Political suppression was the reason why Voronca, Luca, and Isou left Romania as well.

$<\mathrm{P}>$ From a transnationalist perspective, these avant-garde networks are nonessentialist and fluid in that they change over time. Characteristically, transnational 'spaces comprise combinations of ties and their substance, positions within networks and organizations, and networks of organizations that cut across borders of at least two national states' ${ }^{61}$ Indeed, the contribution of the 'other transnationalism' occurred in the same cultural space with the production of the French avant-garde, thus giving it a transnational dimension between the late 1910s and the

\footnotetext{
${ }^{60}$ Brauner to Breton, 12 July 1938, Paris, Fonds André Breton, BRT C 232 1.2 / 2, Bibliothèque Kandinsky.

${ }^{61}$ As aesthetics, groups, and transnational ties evolve, they give rise to transnational spaces. Although such spaces do not exclude development, they are 'relatively stable, lasting and dense sets of ties reaching beyond and across borders of sovereign states' (Faist, 'Diaspora and Transnationalism', p. 13).
} 
1950s. Even though Romanian Jewish artists became established in France, they seldom severed their ties with Romania completely. For instance, Tzara visited Romania in 1947. He inquired with local cultural figures about the current affairs of Romania, only later to describe the country as virtually unrecognizable. ${ }^{62}$ Tzara was by then already a member of the French Communist Party, which caused a rift between him and Brauner and Luca. ${ }^{63}$ Regardless of their occasional disagreements, they all occupied a liminal state between two countries, being at home neither here nor there, thus constituting a transnational space.

$<\mathrm{P}>$ Occupying such a liminal space that connotes homelessness meant that the Jewish writer provided a marginal voice regardless of their true existential situation. Sernet pinpointed the experience of outsiderdom in the transnational space:

\begin{abstract}
$<$ XTT $>$ Vivant en marge de la vie. Seul, en marge de la solitude. Révolté, en marge de la révolution. Rêvant, en marge du rêve. Pensant, en marge de la pensée. Ignorant, en marge de l'ignorance. Mort (mourant) en marge de la mort (le seul domaine qu'il me soit permis comme paria: la zone en marge de tout.). L'état de paria n'est pas nécessairement un en dessous — il est surtout un en dehors. ${ }^{64}$
\end{abstract}

$<\mathrm{TX}>$ In this note, Sernet identifies himself with a pariah, which was a common anti-Semitic slur at the time, and his personal existential experience seems to have been that of a 'close other' - not completely unlike Voronca's identification with Ahasuerus or Luca's 'étranjuif'. However, the

\footnotetext{
${ }^{62}$ See Hentea, TaTa Dada, pp. 269-70.

${ }^{63}$ See Irina Livezeanu, 'From Dada to Gaga: The Peripatetic Romanian Avant-Garde Confronts Communism', in Littératures et pouvoir symbolique: Colloque tenu à Bucarest (Roumanie), 30 et 31 mai 2003, ed. by Mihai Dinu Gheorghiu and Lucia Dragomir (Piteşti: Editura Paralela 45, 2005), pp. 239-53 (p. 252).

${ }^{64}$ Manuscript notes by Claude Sernet; quoted in Michel Gourdet, 'Claude Sernet in the AvantGarde: Itineraries from Romania to Paris', Dada/Surrealism, 1 (2015). <https://doi.org/10.17077/0084-9537.1298> [accessed 30 September 2018]
} 
word 'margin' should here be understood as also an aspect of poetic endeavour rather than merely ethnic-cultural marginalization. This aspect allows Sernet to illuminate such areas of life one tends not to associate with margins and which may be more closely related to the activities of the avantgarde (such as revolt or dreams in their utopian sense). Yet, such a comprehensive marginal aspect also emphasizes a certain willingness to retain the margin. One of its manifestations was the adoption of the 'marginal' Kabbalistic topos.

$<\mathrm{TB}>$

\section{$<\mathrm{SH}>$ Conclusions}

$<\mathrm{TX}>$ It was mainly Jewish poets who introduced Kabbalistic techniques and themes into francophone avant-garde literature in the first half of the twentieth century. The Kabbalah was a source of avant-gardist textual techniques, a fact that signals that these so-called 'new' techniques were not at all novel, but were instead readily available and independent of national languages as a transnational literary idiom. For Jewish artists, the anti-nationalism of the avant-garde was particularly inviting since the European Jewish population lived in a state of diaspora across the Continent. The religious tradition with its ties to Jewish law provided extra-territorial features in the social reality of European Jewry. Indeed, for avant-garde artists of Jewish background, a primary dilemma was how to strike a balance between the historical continuity provided by religion and ethnicity and the novel aesthetic inventions that militated in favour of an explicit break with tradition. The avant-gardes often promoted anti-religious stances, as organized religion was seen by many to be outmoded, even though in reality multiple forms of religious thought and spirituality were cultivated in these groups.

$<\mathrm{P}>$ Jews active in the avant-gardes were anti-traditionalists, thus unfitting for the established historical narratives of both modernism and Jewishness. Against an orthodox- or even secular-bourgeois-assimilated Jewish backdrop, Jews active in the avant-garde were an anomaly. This existential situation, however, became a unifying feature for this particular group of people, 
who were connected with each other directly or through various intermediaries in the transnational space. The other francophone transnationalism in the avant-garde emerged through a transnational network that was based on bilateral cultural co-operation. Furthermore, the transnational space they created enabled the movement of influences derived from the Jewish tradition without rendering their works as particularly 'Jewish' in character.

$<\mathrm{P}>$ The literary transnationalism present in the works of these authors maps the intersections of geo-cultural identities and imageries. The positions of 'close others' and 'double outsiders' illuminate that there was really no conventional culture the avant-gardists could assimilate into, as the transnational avant-garde provided none itself. This transnational and modern network also prohibited a sense of belonging to the (transnational) religious and national(ist) communities. It is here where the Kabbalistic topos provides an implicit affiliation with an ethniccultural tradition, which is a transnational rather than autochthonous literary system. 